\title{
The Implementation of Reciprocal Teaching Method (RTM) in Developing Reading Comprehension of the Second Grade Students of SMAN 2 Bantaeng
}

\author{
Andi Bulkis Maghfirah Mannong \\ bulkismaghfirah@unismuh.ac.id
}

\section{Makassar Muhammadiyah University, Indonesia}

\begin{abstract}
This research is conducted to find out : (1) whether (or not) the implementation of Reciprocal Teaching Method develop the reading comprehension of the second grade students of SMAN 2 Bantaeng, and (2) to find out whether (or not) the use of Reciprocal Teaching Method interest the second grade students of SMAN 2 Bantaeng.This research employed a quasi-experimental. The population of this study was second grade students of SMAN 2 Bantaeng. This research uses cluster random sampling technique. Samples of students included in two classes; 25 students in the experimental class and 25 students in the control class. Data were analyzed SPSS version 20.0. This study shows an increase in learning outcomes of the students in the classroom Improved student learning outcomes from posttest of control with an average score of 80.23> 76.40-test level of significance of 0.05 where the value of the value is higher than the significant level $(0,000<0,05)$. The average value of student interest in the experimental class is 65.14 where the value of standard deviation is 9,078 and categorized as interested. Thus, it can be concluded that the use of RTM improves reading comprehension of students and students who are interested in learning reading comprehension.
\end{abstract}

Key words: Reciprocal Teaching Method, Reading Comprehension, Interest.

\section{INTRODUCTION}

Reading is often characterized as a receptive skill in which one looks at and attempts to understand what has been written in a wide variety of printed and online materials. According to Grellet (1987), taking written text can be understood as an extracting the information needed from it as accurately as possible. Ordinary People read because they want to get information about a particular subject. People read variety of texts such as signs, timetables, directories, maps, letters, tables, application forms, stories, textbooks, instructional, leaflets and the like in order to get facts, exchange ideas, enjoy their leisure time, express feelings, etc. From a technical perspective, reading comprehension had been defined as a dynamic mental activity in which reading focuses on the text to extract meaning (Farhadi, 2005).Understanding is the most important way to learn English and they had a close similarity to an effective conversation style.Belets in Kirmizi (2009) who understands reading allows students to become educated living life. In addition, Allen, et.al in Kirmizi (2009) determined an effective reading process on the use of effective reading comprehension strategies.

Furthermore, reading is a vital aptitude that assists students in process of teaching and learning, national examination, even in proficiencies test (TOEFL and 
IELTS). Pintrichet.al. (1999) state that reading is known as a crucial skill for professional successful and academic learning. In some academic subject areas, school success is dependent on knowing how to read, understand what has been read, and apply the content to future learning.

In fact, based on the preliminary observation at SMAN 2 Bantaeng, the researcher discovered that most of the second grade students find it difficult to comprehend texts especially narrative text. Through interviews with English teachers, the teacher discusses some of the difficulties requested by the teaching compilation teacher. For example, the teacher stated that students did not pay attention during reading lessons. They discuss with their colleagues if he asks to explain the text using teamwork. Likewise, her compilation guides them to read the text aloud, they seem confused and uninterested. In interviews with several students, they say that the students had implicit difficulties and explicit information from the text.

It is also evidence from the score of task in answering the questions based on the text. From 32 students who did the task, the studentse mean score from the test was 70. This score included in fairly classification. So, it can be inferred that the students reading comprehension is enough. To address student problems, researchers discussed using Reciprocal Teaching Methods (RTM) as an alternative method for teaching reading. RTM is a good method for solving problems with students in understanding reading (Blazer, 2007). RTM uses four strategies to understand: summarize, question, predict and clarify, (Brown, 1984). These strategies help to learn to read the development of understanding their own reading (Hosenfeld, et al., 1993). Students work in groups of four or five. As Palinscar and Brown (1984) stated, a group will be divided into five roles, namely leaders, forecasters, explaners, questioners, and summaries.

\section{LITERATURE REVIEW}

\section{Previous Related Studies}

A quantitative study used a quasi-experimental design who was conducted by Choo, Eng and Ahmad (2011) where involved 68 students with lower skills in Malaysia from the fourth to sixth Grade. The findings showed a significant improvement in the post-test results of the experimental group supported using RTM compared to the control group

Freihat and Makhzoomi (2012) further in using RTM in reading training for students. The study was conducted with 50 Jordanian students and it proved that RTM was needed in reading students' abilities.

Similarly, Jafarigohar and Soelaimani (2013) access RTM applications with 45 Persian students. Their findings prove that RTM improves with reading comprehension of students. 
Also, Rosenberger (2011).Camden Region in the United States. Based on data from his studies, he supports and enhances the students' reading comprehension skills.

\section{Some Pertinent Ideas}

\section{Reciprocal Teaching Method}

Palincsar and Brown (1984) discuss the method of discussion. Their program is called reciprocity (RT). RT is "ubiquitous learning techniques." (Glaser, 1990). Palincsar and Brown (1984) describe understanding (by considering decoding abilities that are appropriate to the product "(1) consideration text, (2) reader knowledge and text content, and (3) used to improve understanding of strategies and retention, and support support"

The procedure for teaching reading using RTM is quoted by Palinscar and Brown (1984) cited by the National Behavioral Support Service (n.d) as follows:

1. Before students learn to apply this method in their own group, the trainer must demonstrate the model first. The first coach presents all strategies during reading. The trainer reads the text and the model for step four: summarizes, clarifies, questions, and estimates with students

2. A group of students are selected, and are different roles namely summaries, questioners, explainers, and predictors.

3. Next, ask the student group to read the paragraph of text. Recommendations for recording such as underlining, coding, etc., when reading.

4. Students selected as predictors help you connect before writing or making predictions about the topic before discussing. Then, the trainer asks students to discuss their results with their team. Then they finished reading the text again to agree to their predictions. Next, the question questions help questions and answer questions about questions for detailed questions. The summarizing task is to help the group in finding what the text about based on their peers and their point of view. Clarification helps groups find words and sentences and ways to resolve these difficulties.

5. Students play a role with their peers in their group. Again the students repeat the process consistent with their new role. After the entire text has been read.

6. The trainer asks students to choose a strategy until they have the ability to use this strategy independently.

\section{Reading Comprehension}

Souvignier, et. Al (2006) "In addition, in the reading process, the reader not only needs to understand" (reading and considering, reproducing, learning from, and reproducing, learning from, and learning), the direct meaning of what he reads, 
but he also needs corrected the meaning of the text implied. According to Tierney et al. (2005) explains that reading is not only studying to get words, but also studying to understand texts (Karbalaei, 2010, p.166).

Pressley (2002) states that reading involves a lot of cognitive capacity which is available for understanding the reading materials.

Researchers understand that readers are required to employ a posteriori knowledge in examining the text and form new ideas while reading for comprehension. According to Guterman (2003), "the more knowledge a person brings to his or her reading, the more he or she will understand the text." Some other researchers (e.g., Lau, et.al, 2003) maintain that for a successful reading comprehension exercise the reader has to be more active, evaluate the text, can foresee the events in the text, be able to reread for better understanding and finding inconsistencies, assess his/her comprehension; he/she also will need to use his/her prior knowledge and monitor his comprehension.

Block, et.al (2002) explains that reading comprehension is usually considered as a process in which several elements are integrated. These elements are the ability to decode written materials, reader"s first knowledge of the text, his/her vocabulary knowledge, and the reading strategies to comprehend the text. According to them, "understanding the importance of more than 30 cognitive and cognitive processes including clarifying meaning, summarizing, drawing conclusions, predicting, etc." (Block, et. Al, 2002). In addition, Trabasso et. Al (2002, p. 177) states, "Strategies understand specifically, procedures that are learned actively, competent, selfapproved, and deliberate reading"

Learning to read while reading for meaning or understanding. Reading for meaning in consent is an attempt to understand the text.Tabatabaei, et.al (2014) states that reading comprehension, basically, is known as an interactive process of meaning making between the reader and the author through the text which involves mental activities and background knowledge. On the word, reading comprehension means understanding and gaining meaning from the words read. It is a process when a reader interacts with the text and makes meaning from the text they read (Chegeni, et.al, 2014).

Rice $(2009$, p. 2) This is the process by which conversation goes with text to build meaning. As an understanding of reading texts with understanding. This is the process of understanding connected words, sentences, and sayings. Grabe, et.al (2002) assert that reading comprehension is remarkably complex, involving many lower and higher-level processing skills that are coordinated in very efficient combinations. This is the very point at which ESL and EFL learners confront tremendous problems in the act of reading, because they do not adopt an interactive orientation towards the entire written text (Carrell, et.al, 1988). For example, foreign language learners can read in small text units such as clauses and sentences; nonetheless, they need more experience to form the correct global meaning of the written text. 


\section{Interest}

When people talk about interest, they will think about our positive response or attitude to something we like, enjoy and appreciate which make us having a desire to do. To clearly what actually interest means some theorist will define it. According to Good (1959) explains that interest is the attitude of the subjectobject, considerations related to perception and an intellectual combination in understanding and curiosity by experience. Interest is feeling of desire to know or to learn about something has a positive attitude towards something he/she really likes and enjoys. When talking about interest, we will think about positive response or attitude to something we like, enjoy, and appreciate which make us having desire to do. Therefore, Hornby (2002) defines interest as : 1) Condition to know or studying about something or somebody; (2) Quality that attracts attention or curiosity, which attracts someone's attention; and (3) Something that is of concern to someone.

\section{METHOD}

\section{Design and Samples}

This research applied experimental method. In this experimental design, it required at least two classes, namely control and experimental class. The sample of experimental class consisted of 25 students and control class consisted of 25 students. They were the second grade students of SMAN 2 Bantaeng. Both of two groups were given the same pretest and posttest. They were also received the same reading material of the narrative text. The difference here, the experimental class was taught using RTM strategy while the control class was taught using Three Phase Technique.

\section{Instrument and Procedure}

Two kinds of instruments- reading test and questionnaire were applied in this research. The reading test administered in pretest and posttest. Pretest was conducted before the treatment to know the prior knowledge of students to assess their competence in reading comprehension while post-test was held at the end of the treatment to know the improvement of the students ${ }^{\text {ee }}$ reading comprehension after giving the treatment. Both of control and experimental group and were given the same topic of the test. The tests consisted of multiple choice as much as 30 items. The material of the test is narrative text.

The treatment was conducted for six meetings in both of group. In experimental group was taught using RTM and control group was taught using Three Phase Technique. There are six titles of narrative text which was used in the teaching and learning process. In the first until six meetings, the students ${ }^{\text {ee }}$ activities was same but the different is the title of the text that used in learning process. The 
questionnaire was administered to find out the studentse interest in learning English by using RTM. The questionnaire consisted of 20 items.

\section{Data Analysis}

To examine the effectiveness of RTM on students ${ }^{\text {ee }}$ reading comprehension toward the method, two major statistical procedures were applied: (1) descriptive statistics, including the frequency, descriptive static which calculated the standard deviation and the students ${ }^{\text {ee }}$ mean score and; (2) Inferential analysis, including independent test. Meanwhile, to analyze the students ${ }^{\text {ee }}$ interest toward RTM, Likert Scale was used.

\section{RESULT AND DISUSSION}

\section{The Students' Improvement in Reading Comprehension by Using RTM}

The students' score of pre-test and post-test in reading comprehension for Exprimental and Control Class

The table 1 is the statistically summary of the students ${ }^{\text {ee }}$ pretest and post-test in reading comprehension. The statistical summary depicted in table 1 below shows that the total subjects is 36 students. The score achieved by the students tend to get increased from pretest to post-test.

Table 1

The statistical summary of the students' Pretest and Post-test in Reading Comprehension for Control and Experimental Class

\begin{tabular}{|c|c|c|c|c|}
\hline \multirow{2}{*}{} & \multicolumn{2}{|c|}{ Pretest } & \multicolumn{2}{c|}{ Posttest } \\
\cline { 2 - 5 } & $\mathrm{E}$ & $\mathrm{C}$ & $\mathrm{E}$ & $\mathrm{C}$ \\
\hline $\mathrm{N}$ & 25 & 25 & 25 & 25 \\
\hline Mean & 70.09 & 72.00 & 80.23 & 76.40 \\
\hline Std.Deviation & 5.495 & 5.573 & 3.896 & 6.246 \\
\hline
\end{tabular}

The data in table 1 shows that the comparison of pretest and posttest in reading comprehension achievement on experimental class shows that there was a significant difference. It was proved by the statistical summary that the mean score of pretest was categorized as ,fairly good ${ }^{\text {ee }}$ while the mean score of posttest was categorized as ,very good ${ }^{\mathrm{ee}}$. It means that overall it indicated that there was a significant difference on experimental class test result in pretest and post-test.

The control class shows the difference but it is not so significant. By the statistical summary, the students mean score of pretest was categorized as „fairly good while the mean score of post-test was categorized as ,good ${ }^{\text {ee }}$. Overall, the students 
reading comprehension in control class on posttest were higher than post-test although they were not really significant.

The percentage of the students' performance of pretest and posttest in Experimental Class and Control Class

Table 2

The Rate Percentage and Frequency of the Students' Scores of Pretest and Posttest in Experimental class and Control Class

\begin{tabular}{|c|c|c|c|c|c|c|c|c|c|}
\hline \multirow{2}{*}{ Classification } & \multirow{2}{*}{ Score } & \multicolumn{3}{|c|}{ Experimental Class } & \multicolumn{4}{c|}{ Control Class } \\
\cline { 3 - 10 } & & \multicolumn{2}{|c|}{ Pretest } & \multicolumn{2}{c|}{ Posttest } & \multicolumn{2}{|c|}{ Pretest } & \multicolumn{2}{c|}{ Posttest } \\
\cline { 3 - 10 } & & $\mathrm{F}$ & $\mathrm{P}(\%)$ & $\mathrm{F}$ & $\mathrm{P}(\%)$ & $\mathrm{F}$ & $\mathrm{P}(\%)$ & $\mathrm{F}$ & $\mathrm{P}(\%)$ \\
\hline Excellent & $96-100$ & 0 & 0 & 0 & 0 & 0 & 0 & 0 & 0 \\
\hline Very Good & $86-95$ & 0 & 0 & 5 & 14 & 0 & 0 & 0 & 0 \\
\hline Good & $76-85$ & 5 & 20 & 17 & 68 & 10 & 40 & 12 & 48 \\
\hline Fairly Good & $66-75$ & 5 & 20 & 3 & 12 & 10 & 40 & 11 & 44 \\
\hline Fair & $56-65$ & 15 & 60 & 0 & 0 & 5 & 20 & 3 & 12 \\
\hline Poor & $36-55$ & 0 & 0 & 0 & 0 & 0 & 0 & 0 & 0 \\
\hline Very Poor & $0-36$ & 0 & 0 & 0 & 0 & 0 & 0 & 0 & 0 \\
\hline Total & & 25 & 100 & 35 & 100 & 35 & 100 & 35 & 100 \\
\hline
\end{tabular}

The comparison between control and experimental class and in the pretest result showed that there was no significant difference of both groups in reading comprehension. It was proved by the result pre-test in both groups that most of students (15 or 60\%) in experimental class achieve „fair ce category almost same in control class where it was attained by 10 or $40 \%$ students.

The post-test score in control and experimental class however showed that there was significant difference in the post-test result of both groups. Most of students of experimental one class namely 5 students or $14 \%$ achieved very good category; while in the control group, most of the students (12 or $48 \%$ ) were categorized as ,goode.

\section{Test of Significance (T-Test)}

The hypotheses were tested by using inferential statistic. In this case, the researcher used t-test (testing of significance) for independent sample test. It was important to examine the significant differences between the results of the mean scores of students in the pretest and posttest in the control and experimental class. The t-test results are calculated using SPSS version 20.00. After using the statistics, the researcher found the probability value of t-test as presented in the following table. 
Table 3

Test of Significance (t-test) for Control Class and Experimental Class in Pretest and Posttest

\begin{tabular}{|c|c|c|c|c|c|c|c|c|c|}
\hline & \multicolumn{2}{|c|}{$\begin{array}{l}\text { Levenee"s Test of } \\
\text { Equality of } \\
\text { Variances } \\
\end{array}$} & \multicolumn{7}{|c|}{ t-test for Equality of Means } \\
\hline & \multirow[t]{2}{*}{$\mathrm{F}$} & \multirow[t]{2}{*}{ Sig } & \multirow[t]{2}{*}{$\mathrm{t}$} & \multirow[t]{2}{*}{$\overline{\mathrm{df}}$} & \multirow[t]{2}{*}{$\begin{array}{l}\text { Sig.2 } \\
\text { (tailed) }\end{array}$} & \multirow[t]{2}{*}{$\begin{array}{l}\text { Mean } \\
\text { Difference }\end{array}$} & \multirow[t]{2}{*}{$\begin{array}{l}\text { Std.Error } \\
\text { Difference }\end{array}$} & \multicolumn{2}{|c|}{$\begin{array}{l}\text { 95\% Confidence } \\
\text { Interval of the } \\
\text { Difference }\end{array}$} \\
\hline & & & & & & & & Lower & Upper \\
\hline $\begin{array}{l}\text { Pretest } \\
\text { Equal } \\
\text { variances } \\
\text { assumed }\end{array}$ & ,321 &, 573 & 1,447 & 48 &, 152 & 1,914 & 1,323 & 4,554 & ,726 \\
\hline $\begin{array}{l}\text { Posttets } \\
\text { Equal } \\
\text { variances } \\
\text { not } \\
\text { assumed }\end{array}$ & 10,723 &, 002 & 3,077 & 48 &, 000 & 3,829 & 1,244 & 1,346 & 6,312 \\
\hline
\end{tabular}

Based on the result of data analysis as summarized in table 3 in the pretest of the experimental class and control class, the researcher found that the probability value or $P$-value $(0,152)$ was higherthan the level of significance $\alpha(0.05)$ or $0.152>0.05$. It means that $\mathrm{H}_{0}$ was accepted and $\mathrm{H}_{1}$ was rejected in pretest. In other word, the students ${ }^{\text {ee }}$ ability or level are same before giving the treatment. Whereas, the data in posttest of the control class and experimental class shows that probability value $(P$ value $)$ was smaller than $\alpha(0.000<0.05)$. It means that $\mathrm{H}_{1}$ was accepted and $\mathrm{H}_{0}$ was rejected in posttest. In other words, there was a significant difference of the students ${ }^{\text {ee }}$ score between control and experimental group after receiving treatment.

\section{The Analysis Data of the Students' Interest}

The questionnaire was distributed to the students of experimental clas and after giving treatment in the aim to find out whether the students are interested in learning narrative text by using RTM.

Based on the data analysis of the questionnaire items which referred to the data of the interest of the students on the percentage analysis, the researchers found that none of the students who states negative statement to the use of RTM. The frequency and percentage of the students ${ }^{\text {ee }}$ questionnaire are shown in table 8 as follows: 
Table 4

The Rate of Frequency and Percentage of Students' Interest

\begin{tabular}{|c|c|l|c|c|}
\hline No. & Interval & \multicolumn{1}{|c|}{ Categories } & Frequency & Percentage (\%) \\
\hline 1 & $67-80$ & Very interested & 4 & 16 \\
2 & $54-66$ & Interested & 19 & 76 \\
3 & $42-53$ & Moderate & 0 & 12 \\
4 & $30-41$ & Uninterested & 0 & 0 \\
5 & $16-29$ & Very Uninterested & 25 & 100 \\
\hline \multicolumn{2}{|r|}{ Total } \\
\hline
\end{tabular}

Referred to the analysis of questionnaire in table 4 that the most of students in experimental class, in this case, 19 or $76 \%$ were in positive statements on interval $54-66$ which indicated as ,interested ${ }^{\text {ee }}$. Whereas the rest of them or 3 or $12 \%$ categorized as "moderated". Thus, it can be inferred that the use of RTM interest the students in studying reading comprehension especially narrative text.

Based on the findings above, the comparison of the students improvement in control class and experimental class can be proven by analysing the post-test result. The result shows that the the studentse mean score of post-test and both of the groups is increased after giving the treatment. It can be seen through the students $^{\text {ee }}$ mean score of the pre-test which was 70.09 (fairly good classification) becomes 80.23 (good classification) in the post-test for the experimental class, while the students ${ }^{\text {ee }}$ pre-test for control class was 72.00 (fairly good classification) becomes 76.04 (good classification) in the post-test.

\section{CONCLUSION AND SUGGESTIONS}

Finally, the researcher concluded that RTM can enhance students ${ }^{\text {ee }}$ reading comprehension achievement of the first grade students of SMAN 2 Bantaeng.It"s proved by the students ${ }^{\text {ee }}$ mean score in experimental group was 80.23 higher than the students ${ }^{\text {ee }}$ mean score control class was 76.40. In another side, the questioners consist of 20 items which is whether the method are not interesting and helpful for the students got higher scores compared to the others. The researcher found that all of the studentse activities from all of the indicators of interest were reached which could be seen on the students se involvement, feeling pleasure, attraction, and attention in using RTM.

Based on the conclusion above the researchers gives suggestions as follows; (1) since RTM technique enables the learners to comprehend reading text in interesting way, the researcher suggests this technique to be used by the English teacher of SMAN 2 Bantaeng, and (2) further research might explore more about the usefulness ofRTMtechnique to enhance students ee engagement, motivation, and achievement in learning English. The researcher also recommends for future 
research to investigate the appropriateness of the technique for learner style of learning English.

\section{REFERENCES}

Blazer. (2000). The implementation of RTM among the students of Iranian University. Journal of Language Teaching and Research, 2 (1).

Block, C. C., \& Pressley, M. (2002). Introduction. In C. C. Block \& M. Pressley (Eds.), Comprehension instruction: Research- based best practices (pp. 17). New York: Guilford Press.

Brown, C. (2000). Identifying Factors which Promote or Hinder the Successful Transfer of StaffDevelopment to Classroom Practice. Unpublished Doctoral Dissertation. Texas A and M University

Carrell, P.L. (1988). Metacongnitive Strategy Training for ESL Reading. TESOL Quarterly, 23, 647-673.

Chegeni, N., \&Tabatabei, O. (2014). Lexical Inferencing: The Relationship between Number and Density of Lexical Items and L2 Learners Reading Comprehension Achievement. Journal of Language Teaching and Research, 5 (2), 306-312.

Choo, T. O. L, Eng, T. K., \& Ahmad, N. (2011). Effects of reciprocal teaching strategies on reading comprehension. The Reading Matrix, 11(2): 140-149.

Farhadi, H. (2005). Techniques for Effective Reading. Iran: Iran University of Science and Technology.

Freihat, S. and Makhzoomi, A.K. (2012). The Effect of theReciprocalTeachingProcedure (RTP) on Enhancing EFL Students' Reading Comprehension Behavior in a University Setting. International Journal of Science and Humanities, 2(5).

Good, (1959). The Dictionary of Education. New York: McGraw-Hill Book Company.

Grabbe, W. (1988). Current Developments in Second Language Research. TESOL Quarterly, 25, 375-406.

Grellet, F. (1987). Developing Reading Skills. Cambridge: Cambridge University Press. 
Guterman, E. (2003). Integrating Written Metacognitive Awareness Guidance as A Psychological Tool to Improve Student Performance. Learning and Instruction, 13(16), 633-651.

Hosenfeld, et al. (1993). Activities and Materials forImplementing Adapted Versions of Reciprocal Teaching in Beginning Intermediate andAdvanced Levels of Instruction in English, Spanish, and Frenchas a second/foreignlanguage. Unpublished Manuscript, SUNY at Buffalo.

Hornby, et.al (2002). The Advances Learner's Dictionary to Current English.

Third Edition. London: Oxford University Press.

Jafarigohar, \& Soelamani. (2013). Impact of RTM in Teaching EFL. Journal of RALs, $6(1)$.

Karbalaei, A. (2010). A Comparison of the Metacognitive Reading Strategies Used by EFL and ESL Readers. Reading Matrix, 10 (5), 165-180.

Kirmizi, S. F. (2009).Relationship between Reading Comprehension Strategy Use and Daily Free Reading Time.Elseiver Journal,2 (2), 4752-4756.

Lau, K., \& Chan, D. W. (2003). Reading Strategy Use and Motivation among Chinese Good and Poor Readers in Hong Kong. Journal of Research in Reading, 26(2), 177-190.

Pressley, M. (2002). Reading Instruction that Works $\left(2^{\text {nd }} e d\right)$. New York:Guilford Press.

Pintrich, R.E., Romeo,G.C., \& Muller, S.A.B. (1999). Integrating Reading Strategies into the Accounting Curriculum. College Student Journal. 33(1): $77-82$

Rice, M. (2009). Research-Based Reading Instruction: Reading Comprehension Skills and Strategies--- Florida Center for Reading Research: Making Connections. Educators Publishing Service.

Souvignier, E., \&Mokhlesgerami, J. (2006). Using Self-Regulation as a Framework for Implementing Strategy Instruction to Foster Reading Comprehension. Learning and Instruction, 16(1), 57-71.

Tabatei, O., \&Khalili, S. (2014). The Effect of RTM on Iranian Preintermediate L2 Reading Comprehension. Journal of Language Teaching and Research, 5 (6), 1368-1380.

Tierney, R. J. \&Readence. J. E. (2005). Reading Strategies and Practices: A Compendium (6th Ed.). Boston: Allyn and Bacon. 
INTERACTION: Jurnal Pendidikan Bahasa: Vol. 5, No. 2; October 2018. ISSN: 2406-9558; EISSN : 2406-9566

Trabasso, T., \& Bouchard, E. (2002). Teaching Readers How to Comprehend Text Strategically. In C. C. Block \& M. Pressley (Eds.), Comprehension Instruction: Research-Based Best Practices (Pp. 176-200). New York: Guilford Press. 